$2015 / 16$

\title{
Aspects of Foundation of Knowledge Base in Decision-Making Tasks for the Needs of Intellectual Robots
}

\author{
Kristine Mezale ${ }^{1}$, Andris Kundzins ${ }^{2}$, Zigurds Markovics ${ }^{3}$ \\ ${ }^{1-3}$ Riga Technical University
}

\begin{abstract}
To ensure an intellectual operation of the robot in decision-making tasks, its control system must have a knowledge base that encompasses a full set of results in the corresponding field. The knowledge base can be based upon several types of decision-making rules, including sets of production rules, which are best presented in the form of decision tables. The present paper investigates the versions of synthesis of decision tables in the fuzzy environment depending on the mutual relationships between criteria.
\end{abstract}

Keywords - Artificial intelligence, decision rules, decision tables, decision trees, decision-making criteria, fuzzy sets, linguistic variables, robot.

\section{INTRODUCTION}

Robot technique has been part of our lives for a while now, and sometimes it can have some intellectual traits. Besides, some systems allow solving managerial and decision-making tasks in the fuzzy environment, where fuzzy sets and linguistic variables dominate, such as positive-small, negative-large, far, near, quite far etc.

Before the Theory of Fuzzy Sets by L. A. Zadeh, only the human could work in such an environment. Nowadays, computer systems and robots can operate there with the help of artificial intelligence.

One of the basic features of artificial intelligence is the existence of a knowledge base that contains the knowledge in a certain field discovered and gained by humans.

One of the essential requirements for the quality of the knowledge base is the coherent structuration and correct formalisation of knowledge so that the computer can readily process the information.

Foundation of a knowledge base to solve some problems in decision-making tasks in the fuzzy environment is the main goal of the present research, especially emphasising the performance of robot technique.

\section{DeFINING THE PROBLEM IN FUZZY DECISION-MAKING}

In literature, solutions can be found to decision-making in the fuzzy environment, e.g. the popular Fuzzy TECH 5.55 used to control the telpher [1], inverted pendulum [2], or road traffic control systems [3], [4], [5].

Despite the lack of numerical information, decision-making in the control of the telpher, inverted pendulum and road traffic control systems is entrusted to computers and robot technique.
All the mentioned examples have a similar structure and type of solution. Decision-making takes place in a polycriterial environment ( 2 or 3 criteria). Input information is presented in the form of linguistic variables [6], [7], e.g. gradations of distance:

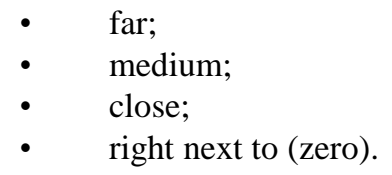

Output value - fuzzy values also have a linguistic gradation, e.g. the gradation of an engine power:

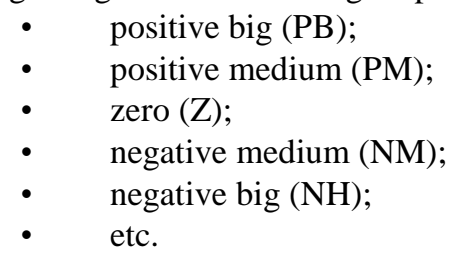

etc.

The compliance of the linguistic variables with the real environment is ensured by the relational functions [8], [9], e.g. shown in Fig. 1, Fig. 2 [1].

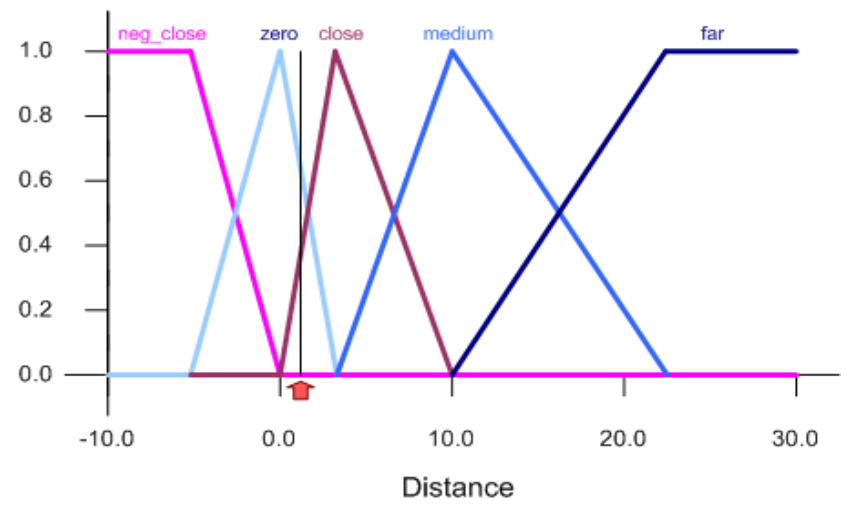

Fig. 1. Possessive function "distance".

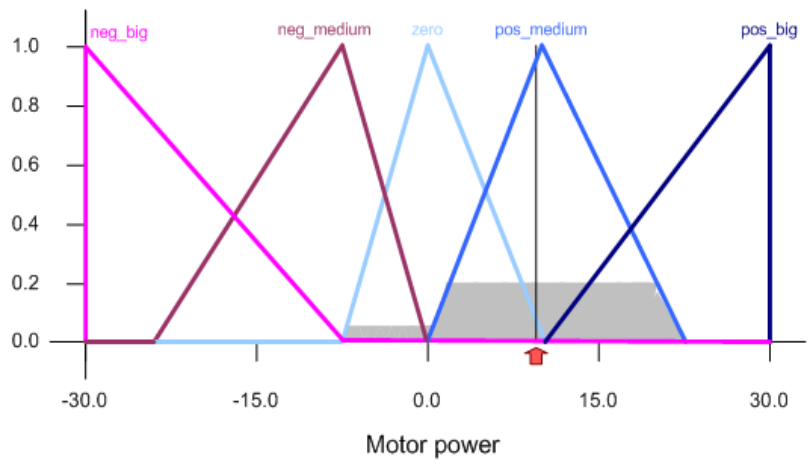

Fig. 2. Possessive function "motor power". 
In all examples, knowledge bases are formed from production rules "IF...THEN", which must also be predefined [10], [11]. They ensure the compliance of the fuzzy decisions (THEN) with the input situations represented by the condition part (IF).

It presents the largest difficulty in these kinds of tasks - how to formulate a set of production rules and determine a full set.

Another important goal of the present research is to find out how much the content of the production rules depends on both the specificity of the task, and type and formal criteria, and what decision-making rules are to be taken into account and used in real solutions.

\section{TyPES OF KNOWLEDGE BASES USED IN PRACTICAL TASKS}

Decision rules (their essence, form, order) can be set in many ways [12]:

- decision trees, Fig. 3;

- sets of production rules, Fig. 4;

- frame structures, Fig. 5 [13];

- decision tables etc.

The distinctive features of these forms determine their usability in solving practical tasks. The decision trees due to their transparency and simplicity are preferred in manual processing, while sets of production rules and frame structures are used in computer processing. However, all of these methods have one downside - they all work best with predefined rules, but are not so well suited for the synthesis of these rules.

If the task is to create a decision rule, the most suitable is the table form, which allows seeing and using different regularities to easily make adjustments and also ensures a foundation of a full set of rules.

A combination of decision rules in a table form that makes up a knowledge base is used in all the aforementioned examples. It is only natural, because the filling of the knowledge base is one of the main objectives of these tasks.

Let us look at various examples:

1. The inverted pendulum example [2] features a robot that has to make a decision in which direction and how fast (v) the cart must be brought into motion for the inverted pendulum not to fall. Input information consists the offset angle of the pendulum $(\alpha)$ from the vertical line and the angular speed of the pendulum motion $\left(\mathrm{V}_{\mathrm{f}}\right)$.

A table of a decision is shown in Fig. 6b. Horizontally in the table the linguistic gradations of the angle $(\alpha)$ are presented:

- $\quad \mathrm{NL}$ - negative large;

- NS - negative small;

- Z-zero;

- PS - positive small;

- $\quad$ PL - positive large.

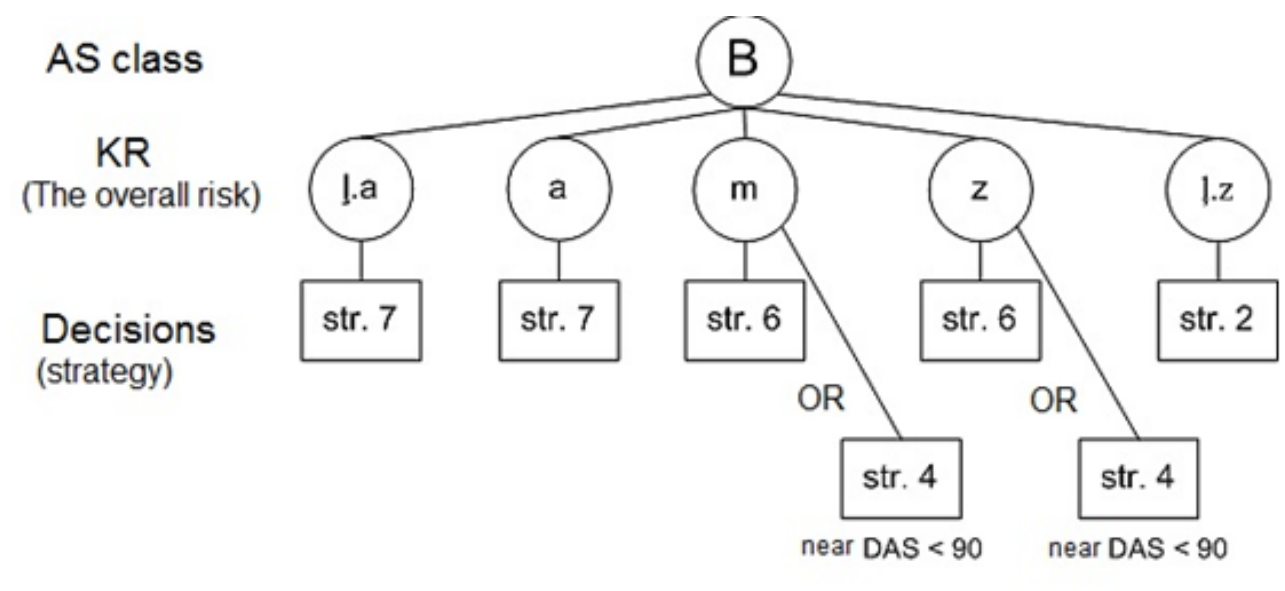

Fig. 3. Decision trees "highest level".

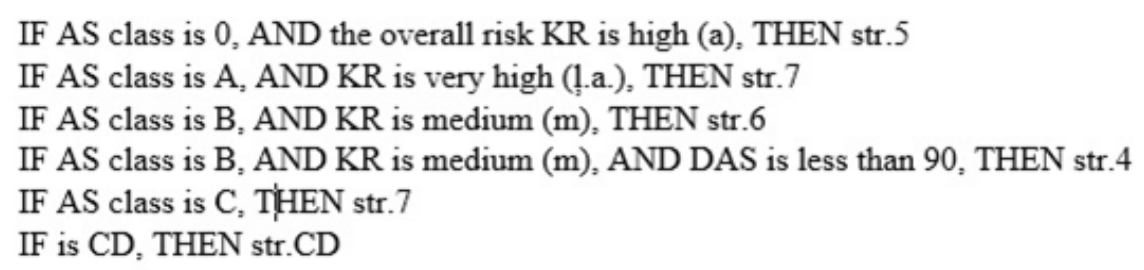

Fig. 4. Sets of production rules "highest level". 
$2015 / 16$

\begin{tabular}{|c|c|c|}
\hline Frame & Slots & Slot values \\
\hline $\begin{array}{c}\text { Immediate intensive therapy } \\
\text { (Strategy 7) }\end{array}$ & $\begin{array}{c}\text { The overall risk } \\
\text { AS } \\
\text { A class }\end{array}$ \\
\hline $\begin{array}{c}\text { Medication } \\
\text { (Strategy 6) }\end{array}$ & $\begin{array}{c}\text { The overall risk } \\
\text { AS }\end{array}$ & $\begin{array}{c}\text { a } \\
\text { A class }\end{array}$ \\
\hline $\begin{array}{c}\text { Frequent monitoring } \\
\text { (Strategy 5) }\end{array}$ & $\begin{array}{c}\text { The overall risk } \\
\text { AS }\end{array}$ & $\begin{array}{c}\mathrm{m} \\
\text { A class }\end{array}$ \\
\hline $\begin{array}{c}\text { Non-intervention } \\
\text { (Strategy 1) }\end{array}$ & $\begin{array}{c}\text { The overall risk } \\
\text { AS }\end{array}$ & $\begin{array}{c}\mathrm{z} \\
\text { A class }\end{array}$ \\
\hline $\begin{array}{c}\text { Strategy 1 } \\
\text { Strategy 7 }\end{array}$ & $\begin{array}{c}\text { The overall risk } \\
\text { AS }\end{array}$ \\
\hline Strategy 3 & $\begin{array}{c}\text { The overall risk } \\
\text { AS }\end{array}$ & $\begin{array}{c}\text { a } \\
\text { B class }\end{array}$ \\
\hline Strategy 2 & The overall risk & AS \\
& The overall risk \\
& AS class \\
\hline
\end{tabular}

Fig. 5. Frame structures "highest level".

a)

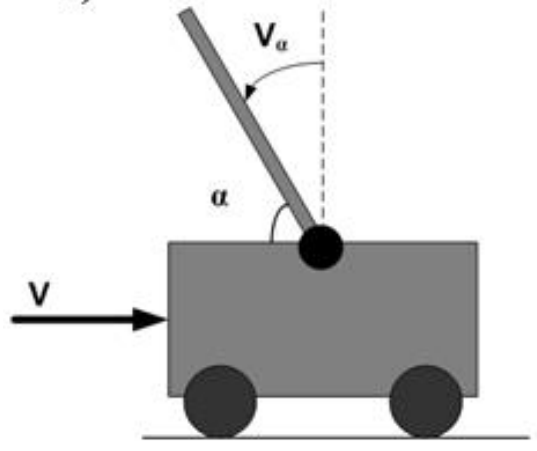

b)

\begin{tabular}{|c|c|c|c|c|c|c|}
\hline \multirow{2}{*}{\multicolumn{2}{|c|}{$\begin{array}{l}\text { The speed of } \\
\text { the platform }-V\end{array}$}} & \multicolumn{5}{|c|}{ Angle a } \\
\hline & & \multirow{2}{*}{$\begin{array}{r}\text { NB } \\
\text { PB }\end{array}$} & \multirow{2}{*}{$\begin{array}{l}\text { NM } \\
\text { PB }\end{array}$} & \multirow{2}{*}{$\frac{Z}{P B}$} & \multirow{2}{*}{$\frac{P M}{P M}$} & \multirow{2}{*}{$\begin{array}{l}\text { PB } \\
Z\end{array}$} \\
\hline \multirow{5}{*}{$\begin{array}{l}\text { Angular } \\
\text { speed Va }\end{array}$} & NB & & & & & \\
\hline & NM & PB & PB & $\mathrm{PM}$ & $Z$ & NM \\
\hline & $\mathrm{z}$ & PB & PM & $z$ & NM & NB \\
\hline & PM & PM & Z & $\mathrm{NM}$ & NB & NB \\
\hline & PB & $Z$ & NM & NB & NB & NB \\
\hline
\end{tabular}

Fig. 6. Inverted pendulum: a) task sketch; b) decision-making rule fragment.

Vertically in the table the linguistic gradations of the angular speed (V) are presented, which match the gradations of the angle $(\alpha)$.

The body of the table contains fuzzy decisions about the direction of the cart and the value of $\mathrm{V}$. These gradations also match the gradations of the angle $\alpha$.

2. Fuzzy TECH example [1] features a horizontallymoving telpher crane that carries cargo which is hung in long cables, Fig. 7. In such conditions, the cargo could rock quite hard, making it difficult to land it in the necessary spot.

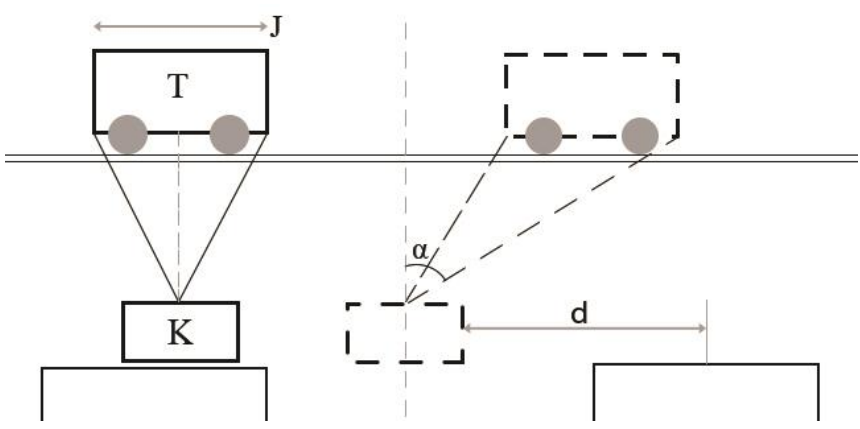

Fig. 7. Telpher crane.
The rocking of the cargo can be offset by deliberately moving the telpher crane. Thus, a decision should be made in which direction and with how much force (or how fast) to move the telpher crane. Input values consist of the offset angle of the cable $(\alpha)$ and distance (d) to the receiver of the cargo.

Linguistic variables of the output values: PL, PS, Z, NS, NL are given higher in the statement of the problem. Input value $\alpha$ has the same exact gradations. Gradations of the input value $d$ are given higher. A fragment of a decision table is shown in Fig. 8.

\begin{tabular}{|c|c|c|c|c|c|c|}
\hline \multicolumn{2}{|c|}{} & \multicolumn{5}{c|}{ Angle a } \\
\cline { 3 - 7 } \multicolumn{2}{c|}{} & NB & NM & Z & PM & PB \\
\hline \multirow{4}{*}{ d } & far & PM & PB & PM & PM & \\
\cline { 2 - 7 } & medium & & NM & Z & PM & \\
\cline { 2 - 7 } & close & & & & PM & \\
\cline { 2 - 7 } & zero & & & Z & & \\
\hline
\end{tabular}

Fig. 8. Decision-making table. 


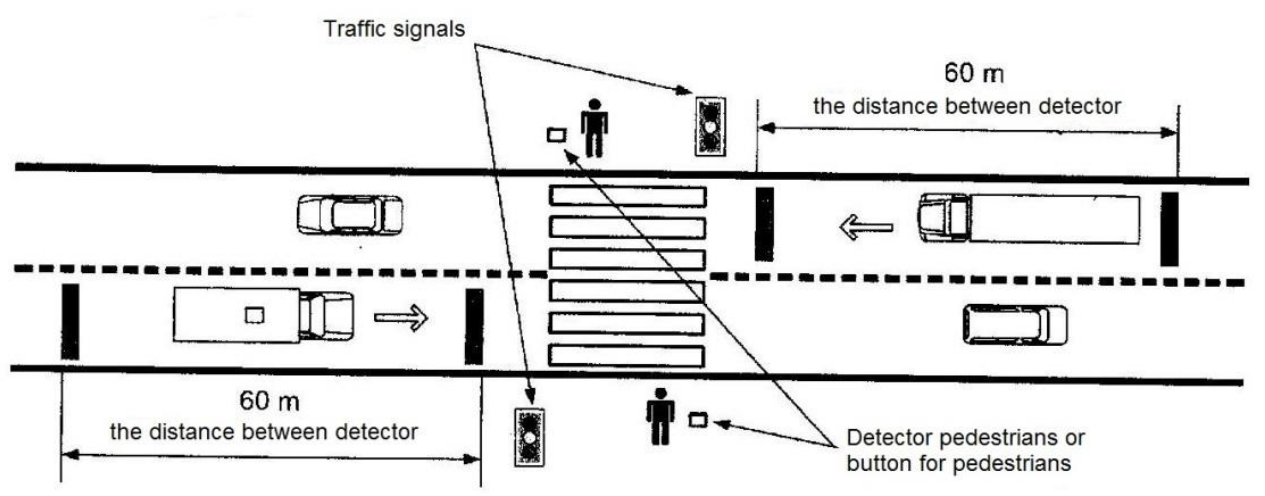

Fig. 9. Controlled pedestrian crossing location.

Unfortunately, this decision table does not allow finding out the method of filling it, and rather resembles an opinion of one person.

3. Road traffic control system example [3] features a highway and a pedestrian crossing with traffic lights. Input information consists of the number of vehicles and the waiting time of the pedestrians. Output value is decision $\mathrm{T}-$ to continue the traffic of the vehicles or decision $\mathrm{P}-$ to switch over the green light for the pedestrians. Here it is possible to see the contradictory nature of decision criteria. They rival each other and are mutually exclusive. No continuity or compromise decisions are possible - either the vehicles or the pedestrians move, but never both. This condition must be strictly taken into account in the knowledge base. An example of traffic control is given in Fig. 9.

4. Crane. Let us imagine a following task. Cargo is being transported from the barge to the coast ramp over a field, Fig. 10. The field could be either empty or partly filled with people. In each situation, a safe route must be chosen which would not endanger people. Input information could consist of:

- border of a field with humans;

- wind speed;

- risk level of the cargo.

What is meant by the risk level is the type of cargo whether it is piece goods, bulk freight, or high-risk cargo (sharp metals, gas cylinders etc.) In this example, criteria are coordinated, because an increase of any of the criteria just moves the route away from the people, only question is - how far.

From the analysis of these examples, it is possible to conclude that:

1. Different methods have to be used to fill the decision tables in different tasks;

2. Each type of the task requires its own methodology of filling the table;

3. To be more objective, it is beneficial to take into account different regularities when creating methodology for solving the tables for each type of the tasks;

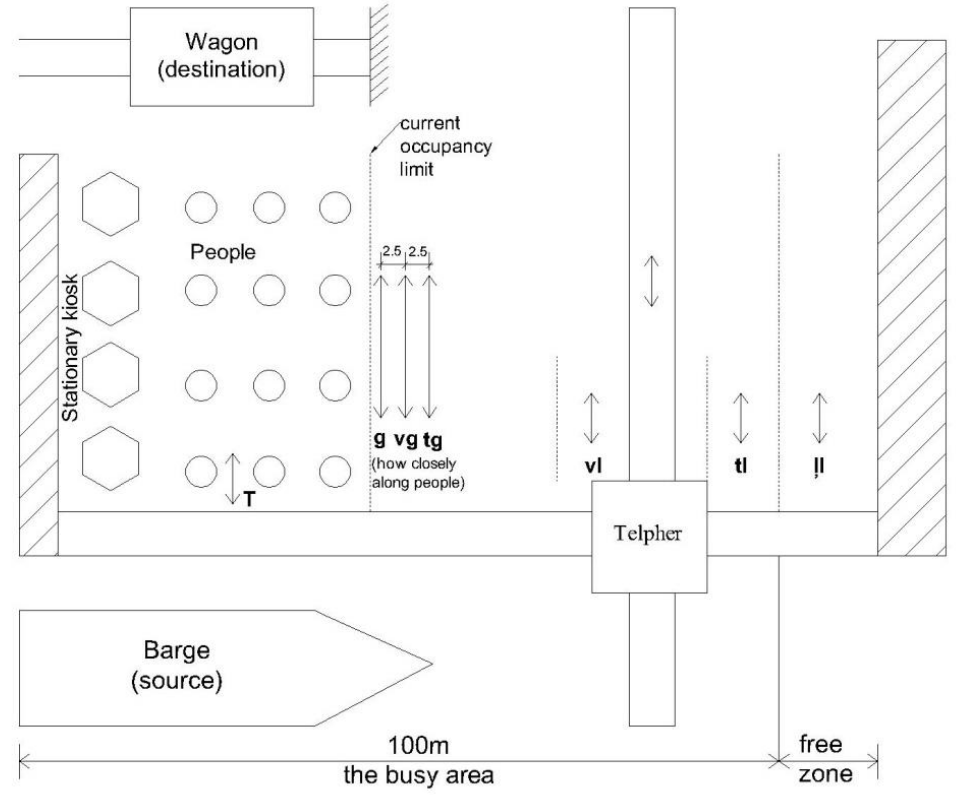

Fig. 10. Example with cargo movement across the square. 


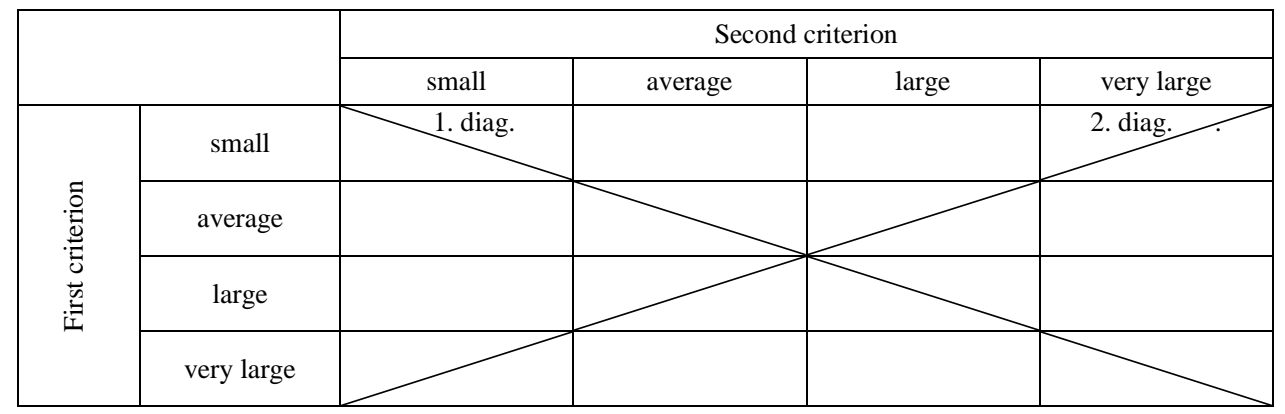

Fig. 11. Decision-making table stencil.

4. Rules should be clearly formulated so that all the experts involved in the solving process would interpret them similarly (if tables are filled by a team of experts according to all the rules of the experiment);

5. Rules can be very different, e.g. when the criteria compete (example 3) or do not compete with each other (example 4);

6. There can be situations when it is necessary and possible to take into account the priority of criteria, but it can also be unnecessary and can reduce the level of objectivity.

\section{Methods OF FILLING THE TABLE}

Let us continue with development of practical methods for some types of tasks. A typical decision table in the fuzzy environment with linguist variables is presented in Fig. 11.

Vertically and horizontally in the table the linguistic gradations of the first criterion and the second criterion can be found. Cells of the table are meant for writing down the fuzzy decisions. A case is examined where one expert creates the fuzzy decisions. The actions of the expert group are not discussed.

Let us list the main requirements for filling the table:

1. the entries have to be as close to the objective reality as possible;

2. the methodology of filling the table has to be clear;

3 . if the task requires to take into account the priorities of the criteria, there has to be a way how to implement it in the table.

\section{A Case with Contradictory Criteria}

A typical example of the situation is from the field of road traffic control (the third example with a highway and pedestrian crossing). There are two criteria:

1. number of vehicles on the highway;

2. waiting time of the pedestrians.

The criteria are mutually exclusive - green light either for vehicles or for pedestrians.

Both criteria in the top left corner of the table are low, while the ones in the bottom right corner are high. It means that the strongest rivalry is in the area around the first diagonal and filling of it is most ambiguous.

An opposite situation is in the area around the second diagonal, where a value of one criterion "small" meets a value of the second criterion "very large", thus determining the decision.

Thus, in the top right corner of the table around the second diagonal or on top of the first diagonal the fuzzy decisions will be in favour of the second (horizontal) criterion - continue the green light for the vehicles (T). In the bottom left corner of the table or under the first diagonal the decision will be in favour of the first (vertical) criterion - switch the green light for the pedestrians (P), Fig. 12.

It is possible to modify the elements of the first diagonal:

a) if pedestrians are to be given priority (schools, kindergartens, old people's homes, hospitals, residential areas with visually impaired people), then entries of the diagonal (??) are replaced with $\mathrm{P}$;

b) if priority is to be given to vehicles, then entries of the diagonal are replaced with $\mathrm{T}$.

In some cases, priority can be given to elements which in Fig. 12 are labelled as P? and T?. These are places where experts can express their different opinions, and these places can be solved with the formal methods of the expert evaluations.

\begin{tabular}{|c|c|c|c|c|c|}
\hline & & \multicolumn{4}{|c|}{ Number of vehicles } \\
\hline & & small & average & large & very large \\
\hline \multirow{4}{*}{ 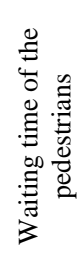 } & small & $? ?$ & $\mathrm{~T}$ ? & $\mathrm{T}$ & $\mathrm{T}$ \\
\hline & average & P? & $? ?$ & $\mathrm{~T}$ & $\mathrm{~T}$ \\
\hline & large & $\mathrm{P}$ & $\mathrm{P}$ & $? ?$ & $\mathrm{~T}$ ? \\
\hline & very large & $\mathrm{P}$ & $\mathrm{P}$ & P? & $? ?$ \\
\hline
\end{tabular}

Fig. 12. Decision-making table. 
It should be noted that in the filling of the elements P?, T?, ?? a side criterion can be used - the distance between vehicles driving in a single lane. If this distance is short, there is some risk of crashes, which is why the mentioned elements can be replaced with $T$. If the distance is long, elements can be replaced with $P$.

\section{A Case with Matching Criteria}

A typical example of the situation is the transportation of cargo over a field that is partly filled with people, (the fourth example, Fig. 10). There are three criteria:

1. distribution of the people in the field (border);

2. risk level of the cargo;

3. wind speed.

Criteria are well-matched because the higher value, the further away the crane route is moved away from the people.

The criteria do not compete with each other even if their values do not match. If one criterion allows a shorter distance from the people, then the decision is made according to the second criterion, which does not allow it.

Situation is made more difficult by the fact that the fuzzy decisions are complex. The first criterion determines the serial number of the virtual corridor of the possible route, which in turn determines (approximately) the distance by which the crane will have to be moved right so that it operates behind the border of the field of humans.

Linguistic gradations of the variable are:

- $\mathrm{T}$ - straight over the field;

- $\mathrm{ml}$ - very little to the right;

- $\mathrm{nl}$ - little to the right;

- vl - quite far to the right;

- $\mathrm{tl}$ - far to the right;

- 11 - very far to the right.

Second part of the fuzzy decision is made of the inner distance in the corridor, which determines just how close to the humans the cargo can be transported taking into account its risk level and the wind speed.

Linguistic gradations of the variable are:

- $\mathrm{g}$ - right along the border;

- $v g$ - quite far away, (up to $2.5 \mathrm{~m}$ );
- $\operatorname{tg}$ - far away from the border. $(2.5-5 \mathrm{~m})$.

These are the fuzzy decisions:

- $\mathrm{vl} / \mathrm{g}$ - quite far to the right, right along the border;

- $\mathrm{tl} / \mathrm{vg}$ - far to the right, quite far away;

- $11 /$ tg - very far to the right, far away from the border.

As the environment consists of three criteria, there will be many decision tables according to the number of gradations of the first criterion.

Let us look at one of the possible decision tables consisting of wind speed and the risk level of the cargo. Table corresponds with the corridor on the first criterion with the value - far to the right, Fig. 13.

First two conditions of the methodology for filling the table are obvious:

1) if there is no cargo (idling), there is no risk and the first row of the column is filled with $\mathrm{T}-$ straight over the people;

2) if this table is made for the situation tl - far to the right, then fuzzy decisions in all other cells will have the first part as tl. If the table were meant for the situation $\mathrm{nl}-$ little to the right, then the first part of the decisions in the cells would be nl.

Further analysis refers to the second part of the fuzzy decisions.

3) Wind speed and the risk level of the cargo do not compete with each other. Bottom right corner of the table features the maximum values of both criteria. That is why decisions are in favour of a long distance from the border of the field of people - far away from the border (tg);

4) Top left corner of the table features minimums of both criteria. That is why the decisions are in favour of a short distance - right along the border $(\mathrm{g})$.

It means that the elements of the first diagonal and their surroundings are easily filled, but the most ambiguous ones are the elements around the second diagonal where the large values of one criterion meet the small values of second criterion. It suggests that elements can have mean values, e.g. vg - quite far away.

\begin{tabular}{|c|c|c|c|c|c|c|}
\hline & & \multicolumn{5}{|c|}{ Many filled (da) --> tl } \\
\hline & & $\begin{array}{l}\text { No wind } \\
\text { (bv) }\end{array}$ & $\begin{array}{l}\text { Moderate w. } \\
\text { (mv) }\end{array}$ & $\begin{array}{l}\text { Medium w. } \\
\text { (vv) }\end{array}$ & $\begin{array}{l}\text { Strong w. } \\
\text { (sv) }\end{array}$ & $\begin{array}{c}\text { Very strong } w \\
\text { (Iv) }\end{array}$ \\
\hline \multirow{4}{*}{ 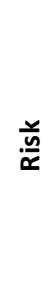 } & No - empty (nb) & $T$ & $\begin{array}{ll}T \\
T\end{array}$ & $T$ & $\begin{array}{ll}T \\
\end{array}$ & $\begin{array}{ll}T \\
T\end{array}$ \\
\hline & Low (mb) & $\mathrm{tlg}$ & $\mathrm{tlg}$ & tl vg? & tl vg? & tl vg? \\
\hline & Medium (vb) & $\mathrm{tlg}$ & tl vg? & tl vg? & tl tg & tl tg \\
\hline & High (Ib) & tl tg & tl tg & tl tg & tl tg & tl tg \\
\hline
\end{tabular}

Fig. 13. Decision-making table. 
$2015 / 16$

It is based on the following logic. A decision has to be made taking into account the most dangerous gradations of a criterion, but the small values of the other criterion reduce this level of risk, compared to the situation when both criteria have large values.

The outlined methodology is used in filling the other decision tables of the task, according to the distribution of the people in the field $\mathrm{ml}, \mathrm{nl}, \mathrm{vl}, \mathrm{tl}, \underline{l} \mathrm{l}$ (Fig. 14).

\begin{tabular}{|c|c|c|c|c|c|c|}
\hline \multicolumn{2}{|c|}{} & \multicolumn{5}{c|}{ A bit filled (ma) --> ml } \\
\cline { 2 - 8 } & $\begin{array}{c}\text { No wind } \\
\text { (bv) }\end{array}$ & $\begin{array}{c}\text { Moderate w. } \\
\text { (mv) }\end{array}$ & $\begin{array}{c}\text { Medium w. } \\
\text { (vv) }\end{array}$ & $\begin{array}{c}\text { Strong w. } \\
\text { (sv) }\end{array}$ & $\begin{array}{c}\text { Very strong w. } \\
\text { (lv) }\end{array}$ \\
\hline \multirow{2}{*}{} & No- empty (nb) & $\mathrm{T}$ & $\mathrm{T}$ & $\mathrm{T}$ & $\mathrm{T}$ & $\mathrm{T}$ \\
\cline { 2 - 8 } & Low (mb) & $\mathrm{mlg}$ & $\mathrm{mlg}$ & $\mathrm{ml} \mathrm{vg}$ & $\mathrm{ml} \mathrm{vg}$ & $\mathrm{ml} \mathrm{vg}$ \\
\cline { 2 - 8 } & Medium (vb) & $\mathrm{mlg}$ & $\mathrm{ml} \mathrm{vg}$ & $\mathrm{ml} \mathrm{vg}$ & $\mathrm{ml} \mathrm{tg}$ & $\mathrm{ml} \mathrm{tg}$ \\
\cline { 2 - 8 } & High (lb) & $\mathrm{ml} \mathrm{tg}$ & $\mathrm{ml} \mathrm{tg}$ & $\mathrm{ml} \mathrm{tg}$ & $\mathrm{ml} \mathrm{tg}$ & $\mathrm{ml} \mathrm{tg}$ \\
\hline
\end{tabular}

\begin{tabular}{|c|c|c|c|c|c|c|}
\hline & & \multicolumn{5}{|c|}{ A little filled (na) --> nl } \\
\hline & & $\begin{array}{l}\text { No wind } \\
\text { (bv) }\end{array}$ & $\begin{array}{l}\text { Moderate w. } \\
\text { (mv) }\end{array}$ & $\begin{array}{l}\text { Medium w. } \\
\text { (vv) }\end{array}$ & $\begin{array}{l}\text { Strong w. } \\
\text { (sv) }\end{array}$ & $\begin{array}{c}\text { Very strong w. } \\
\text { (IV) }\end{array}$ \\
\hline \multirow{4}{*}{$\frac{-\breve{a}}{x}$} & No - empty (nb) & $\mathbf{T}$ & $\mathbf{T}$ & T & $\mathbf{T}$ & $\mathbf{T}$ \\
\hline & Low (mb) & $\mathrm{nl} \mathrm{g}$ & $\mathrm{nl} \mathrm{g}$ & nl vg & nl vg & nl vg \\
\hline & Medium (vb) & $\mathrm{nl} \mathrm{g}$ & nl vg & nl vg & $\mathrm{nl}$ tg & nl tg \\
\hline & High (Ib) & $\mathrm{nl} \mathrm{tg}$ & $\mathrm{nl}$ tg & nl tg & $\mathrm{nl}$ tg & $\mathrm{nl}$ tg \\
\hline
\end{tabular}

\begin{tabular}{|c|c|c|c|c|c|c|}
\hline \multicolumn{2}{|c|}{} & \multicolumn{5}{c|}{ Average filled (va) --> vl } \\
\cline { 2 - 7 } & $\begin{array}{c}\text { No wind } \\
\text { (bv) }\end{array}$ & $\begin{array}{c}\text { Moderate w. } \\
\text { (mv) }\end{array}$ & $\begin{array}{c}\text { Medium w. } \\
\text { (vv) }\end{array}$ & $\begin{array}{c}\text { Strong w. } \\
\text { (sv) }\end{array}$ & $\begin{array}{c}\text { Very strong w. } \\
\text { (lv) }\end{array}$ \\
\hline \multirow{3}{*}{} & No - empty (nb) & $T$ & T & $T$ & T & T \\
\cline { 2 - 8 } & Low (mb) & vl g & vl g & vl vg & vl vg & vl vg \\
\cline { 2 - 8 } & Medium (vb) & vl g & vl vg & vl vg & vl tg & vl tg \\
\cline { 2 - 8 } & High (lb) & vl tg & vl tg & vl tg & vl tg & vl tg \\
\hline
\end{tabular}

\begin{tabular}{|c|c|c|c|c|c|c|}
\hline & & \multicolumn{5}{|c|}{ Fully filled (pa) -->!! } \\
\hline & & $\begin{array}{l}\text { No wind } \\
\text { (bv) }\end{array}$ & $\begin{array}{l}\text { Moderate w. } \\
\text { (mv) }\end{array}$ & $\begin{array}{l}\text { Medium w. } \\
\text { (vv) }\end{array}$ & $\begin{array}{l}\text { Strong w. } \\
\text { (sv) }\end{array}$ & $\begin{array}{c}\text { Very strong } \mathrm{w} . \\
\text { (lv) }\end{array}$ \\
\hline \multirow{4}{*}{ 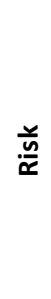 } & No - empty (nb) & $T$ & $T$ & $T$ & $T$ & $T$ \\
\hline & Low (mb) & !l g & !lg & !l vg & !l vg & !l vg \\
\hline & Medium (vb) & $\| \mathrm{g}$ & !! vg & !! vg & !l tg & !l tg \\
\hline & High (Ib) & |̣ tg & I! tg & |̣ tg & !̣ tg & !̣ tg \\
\hline
\end{tabular}

Fig. 14. Other decision-making tables. 


\begin{tabular}{|c|c|c|c|c|c|}
\hline & & \multicolumn{4}{|c|}{ Pendulum angle $\alpha$} \\
\hline & & small & average & large & very large \\
\hline \multirow{4}{*}{ 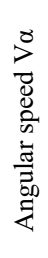 } & small & small & small & average & $?$ \\
\hline & average & small & average & ? & large \\
\hline & large & average & $?$ & large & very large \\
\hline & very large & $?$ & large & very large & very large \\
\hline
\end{tabular}

Fig. 15. Decision-making table for inverted pendulum.

\section{A Case with Conditional Criteria}

A typical example of the situation is the inverted pendulum on a moving cart. Let us look at two examples. In the first situation, the pendulum can fall only to the right side. Let us assume that the movement to the right side, the right angle and the angular speed to the right side are all positive values.

Methodology of filling the table is similar to the situation with the matching criteria, Fig. 15.

Here the filling of the table in the first diagonal and around it is relatively clear: in the top left corner there are the low values of the cart speed, in the bottom right corner - the high and very high values. In the middle section of the diagonal there are the average values. Values of the second diagonal are the most ambiguous ones.

The second situation features a pendulum that can fall either to the right side or to the left.

All the movements and values to the left side are negative, Fig. 16.

Just as before, the elements at both ends of the first diagonal are easily filled in, because the positive gradations of both criteria meet.

The elements at the ends of the second diagonal represent situations when the initial angles are positive, but the pendulum falls to the left side due to some external forces, and vice versa. Values of these elements are the most ambiguous ones.
One of the solutions for the middle section of the table could be the "zero" solution - to do nothing and wait for the situation to move to one of the end states etc.

As we can see from the discussed examples, the methodology of filling the tables can vary, but the order always is the same - first, all of the clear spaces are filled in, then the ambiguous ones are isolated to find an individual approach of filling them.

\section{CONCLUSION}

1. It is rational to start the foundation of a production rules based knowledge base with the table form. Only the table form allows seeing the full set of production rules, i.e. a full set of results, ensured neither by the form of "if then" nor by decision trees.

2. Foundation of the set of all the production rules must be done on the basis of the formal regularities.

3. These formal laws are not the same in all cases. They depend on the nature and type of the decision criteria.

4. Decision criteria can be mutually exclusive, independent, matching, dependant etc.

5. It is beneficial to start the filling of the table of production rules with the cells which can certainly be filled. It allows isolating the ambiguous cells, which have to be filled with specific methods.

6. In the fuzzy decision-making process for the ambiguous cells, one can use:

\begin{tabular}{|c|c|c|c|c|c|c|}
\hline & & \multicolumn{5}{|c|}{ Pendulum angle $\alpha$} \\
\hline & & - large & - small & 0 & + small & + large \\
\hline \multirow{5}{*}{ 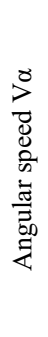 } & - large & -large & - large & - small & - small & - small \\
\hline & - small & - large & - small & 0 & 0 & - small \\
\hline & 0 & - small & 0 & 0 & 0 & + small \\
\hline & + small & + small & 0 & 0 & + small & + large \\
\hline & + large & + small & + small & + small & + large & + large \\
\hline
\end{tabular}

Fig. 16. Decision-making table for inverted pendulum. 
- different existing ratios of importance;

- priorities of criteria defined by knowledge engineers;

- logical connections and charts created by the knowledge engineer;

- evaluations [14] and decisions of a group of experts, taking into account the experiment conditions etc.

\section{REFERENCES}

[1] Passino M.K., Yurkovich S., Fuzzy control, Addison Wesley Longman, Inc., Sand Hill Road, Menlo Park, California, 1998, 43 p.

[2] Passino M.K., Yurkovich S., Fuzzy control, Addison Wesley Longman, Inc., Sand Hill Road, Menlo Park, California, 1998, 50 p.

[3] Kurmeleva O., „Indirect operating mode logic studying automated control systems", Master's thesis, Z. Markovics, Riga, Latvia, RTU, 2006.

[4] Pappis C., Mamdani E., „A Fuzzy logic controller for a traffic junction” IEEE Transactions on Systems: man and cybernetics, 2003, pp. 707 717. http://dx.doi.org/10.1109/TSMC.1977.4309605

[5] Chiu S. „Adaptive Traffic Signal Control using Fuzzy logic,” Intelligent Vehicles Symposium'99, Detroit, 1999, 125 p. http://dx.doi.org/10.1109/IVS.1992.252240

[6] Zadeh L.A., "The concept of a linguistic variable and it's application to approximate reasoning," American Elsevier Publ. Comp., NewYork, 1973, 165 p.

[7] Zadeh L.A., The linguistic approach and its application to decision analysis, Memorandum N, ERL-M576, Berkley, Unio California, 1976, $27 \mathrm{p}$.

[8] Borisov A.N., Krumberg O.A., Fedorov J.P., Decision making in the Fuzzy sets, Riga, Latvia, 1990, 184 p.

[9] Averkin A.N. et al., Fuzzy sets in management models and artificial intelligence. Moscow, Nauka, 1986, $311 \mathrm{p}$.

[10] Watermam D.A., A guide to expert system, 1985, 700 p.
[11] Negnevitsky M., Artificial intelligence: a guide to intelligetn system, Addison Wesley, 2005, 415 p.

[12] Milasivica S., Prancane E., Markovica I., Markovics Z., „Knowledge bases for decision making developmen and estimation", Scientific Journal of Riga Tehnical Universisty, Computer science, vol. 13, Riga, Latvia, 2009, pp. 34-42.

[13] Durkin J., Expert systems, NewYork, 1998, 800 p.

[14] Laurs A., Markovics Z., „Calculation of threshold value by expert methods”, Scientific Journal of Riga Technical University, Technologies of Computer control, vol. 16, Riga, Latvia, 2015. http://dx.doi.org/10.7250/tcc.2015.003

Kristine Mezale was born in 1991. She received the degree of B. sc. ing. from Riga Technical University in 2014. At present, she is a Master student at the Institute of Computer Control, Automation and Computer Engineering, Riga Technical University.

E-mail: kristine.mezale77@gmail.com

Andris Kundzins was born in 1992. He received the degree of B. sc. ing. from Riga Technical University in 2014. At present, he is a Master student at the Institute of Computer Control, Automation and Computer Engineering, Riga Technical University.

E-mail: andzus92@inbox.lv

Zigurds Markovics, Dr. habil. sc. ing., is a Professor (since 1993) of the Institute of Computer Control, Automation and Computer Engineering, Faculty of Computer Science and Information Technology, Riga Technical University.

$\mathrm{He}$ is the author of 148 scientific publications and 3 monographs.

His research interests include: computer control systems, artificial intelligence systems, robotics.

He is a member of the Latvian Association of Professors and Latvian Association of Scientists.

Address: 2, Daugavgrivas Str., Riga, LV-1007, Latvia.

E-mail: Zigurds.Markovics@ rtu.lv

Kristīne Mežale, Andris Kundziňš, Zigurds Markovičs. Zināšanu bāzes izveidošanas aspekti lemšanas uzdevumos intelektuālo robotu vajadz̄̄bām

Lai nodrošinātu robota intelektuālu darbību lēmumu pieņemšanas uzdevumos, tā vadības sistēmā jābūt zināšanu bāzei, kas aptver pilnu notikumu kopu apskatāmajā sfērā. Zināšanu bāze var balstīties uz vairāku lemšanas kārtulu veidiem, tostarp arī uz produkciju likumu kopām, kuru prezentācijai vispiemērotākā ir lemšanas tabulu forma. Darbā aplūkoti lemšanas tabulu sintēzes varianti nestriktā vidē atkarībā no kritēriju savstarpējām attiecībām.

Кристина Межале, Андрис Кундзиныш, Зигурдс Маркович. Аспекты образования баз знаний для принятия решений интелектуальными роботами

Чтобы использовать роботов в задачах принятия решений, их поведение должно быть интеллектуальным, что требует наличие базы знаний в системе управления. База знаний включает себя правила принятия решений, представляемые в различных формах, таких, как множество продукционных правил, множество фреймов, дерево решений, таблица решений. В настоящей работе рассматриваются вопросы создания комплекта таблиц решений в нечёткой среде в зависимости от характера и взаимных отношений критериев выбора решений. 